DOI: $10.5455 / 2320-1770.1 j r \operatorname{cog} 20131204$

Research Article

\title{
Cancer awareness among females of urban slums in their reproductive age group
}

\author{
Mayur S S ${ }^{1}$, Radhika M S ${ }^{2}$, Anshuman $A^{1}$ \\ ${ }^{1}$ Department of Community Medicine, ${ }^{2}$ Department of Pharmacology, SDM College of Medical Sciences and
} Hospital, Dharwad, Karnataka, India

Received: 25 August 2013

Accepted: 5 September 2013

\section{*Correspondence:}

Dr. Mayur S. Sherkhane,

E-mail: drmayurss@yahoo.co.in

(C) 2013 Mayur SS et al. This is an open-access article distributed under the terms of the Creative Commons Attribution Non-Commercial License, which permits unrestricted non-commercial use, distribution, and reproduction in any medium, provided the original work is properly cited.

\begin{abstract}
Background: Cancer is major public health problem affecting millions of people worldwide. The prevalence of cancer is increasing in developing world due to increase in life expectancy, increased urbanization and adoption of western life styles. Thus, the present study was carried out to assess the extent of awareness towards cancer among women of urban slums in their reproductive age group.

Methods: Community based cross sectional study was carried out by interviewing women of reproductive age group residing in urban slums using pre-designed and pre-tested proforma to assess awareness towards cancer. Descriptive statistics was applied to assess the awareness level and the association between two attributes was calculated by chisquare test.

Results: A total of 182 women were interviewed. Out of which $39.56 \%$ were in $20-24$ years age group. $46.15 \%$ were housewives and most of them belonged to middle class families. Though the knowledge regarding cancer, especially about modes of transmission, symptoms and laboratory diagnosis was found satisfactory but was accompanied by misconceptions. $71.43 \%$ women were aware about its prevention, mostly by changing life styles and by getting screening done at regular intervals.

Conclusion: Thus, impetus has to be laid upon screening regarding cancer during reproductive age group and enlightenment of the women about cancer screening centres available at the hospitals, so as to heighten the knowledge of facilities for a better reproductive life.
\end{abstract}

Keywords: Awareness, Cancer, Non-Communicable Diseases, Odds ratio, Urban Slums

\section{INTRODUCTION}

Non-Communicable Diseases (NCDs) are assuming increasing importance among the adult population in both developed and developing countries. ${ }^{1}$ Among NCDs, Cancer is a major public health problem worldwide ${ }^{2,3}$, second leading cause of death in developed and is among the three leading causes of mortality in developing countries after individuals reach 15 years of age. Globally every year, six million people die from cancer, which accounts to $12 \%$ of deaths in the world and ten million new cases are diagnosed, of which more than half occur in developing countries. ${ }^{4}$ In India, Cancer has become one of the ten leading cause of death. It is estimated that there are nearly 2-2.5 million cancer cases at any given point of time. Over eight lakh new cases and four lakh deaths occur annually due to cancer. ${ }^{5,6}$

The prevalence of cancer is increasing in developing world due to increase in life expectancy, increased urbanization and adoption of western life styles. ${ }^{7,8}$ The likelihood of cure from cancer is usually dependent on the stage of disease at diagnosis. Some patients attend their general practitioner with a long preceding history of cancer symptoms, this may be due to lack of the seriousness of the symptoms. ${ }^{9}$ 
The traditional image of cancer is one of fear and pain, over the years the image has improved and many cancers are curable, provided they are detected early by screening and treated effectively at an early stage. ${ }^{10,11}$ Therefore to control clear understanding of factors contributing to development of cancer is necessary. Thus, the present study was undertaken to evaluate the extent of awareness of the women living in urban slums towards cancer.

\section{METHODS}

This community based cross-sectional study was conducted among married females of reproductive age group residing in urban slums, which is an urban field practice area of Urban Health Centre, attached to tertiary care hospital, Dharwad, Karnataka. The Urban Health Centre covers a population of 30,000 and provides quality primary health care to the urban slum dwellers and the population of nearby catchment area.

\section{Pre-study}

Prior to the study, a pilot study was conducted involving 20 married women in reproductive age group over a period of one month (November 2011) to assess the feasibility of pre designed proforma. The tested proforma was then utilized in the present study after satisfactory reformations were made in it.

\section{Present study}

After the pilot study, present study was conducted for a period of six months from December 2011 to May 2012. The study was carried out by interviewing married women in the age group of 15 - 45 years by using the tested proforma after signing a written consent form on voluntary basis and confidentiality was assured before the data collection was initiated.

A house-to-house survey, using convenient and systematic random sampling (every $5^{\text {th }}$ house considered) was done, case identification was carried out with the help of medical social workers equipped with the proforma. The case load was cross-checked to reassure that the cases were not missed.

A total of 182 women in the study area were surveyed. Relevant information was recorded in the pre-designed and pre-tested proforma covering sociodemographic characteristics like age, occupation, literacy status, socioeconomic status and knowledge regarding modes of transmission. Misconceptions towards cancer patients were also noted.

Statistical analysis: Using descriptive statistics, knowledge regarding cancer was evaluated and association between two attributes was analyzed using Chi-square test. Statistical significance was set at $5 \%$ level of significance $(\mathrm{p}<0.05)$.

\section{RESULTS}

It was found that maximum $72(39.56 \%)$ were in the age group of 20-24 years and $114(62.64 \%)$ had completed higher school education. Almost 84 (46.15\%) women were housewives and $75(41.21 \%)$ were from socioeconomic class III - middle class families according to Modified B.G. Prasad classification $2011^{12}$ (Table 1).

Table 1: Sociodemographic characteristics of women $(n=182)$.

\begin{tabular}{|lll|}
\hline Age ( years) & Number & Percentage (\%) \\
\hline $15-19$ & 06 & 03.29 \\
\hline $20-24$ & 72 & 39.56 \\
\hline $25-29$ & 58 & 31.87 \\
\hline $30-34$ & 21 & 11.54 \\
\hline$\geq 35$ & 25 & 13.74 \\
\hline Educational status & Number & Percentage (\%) \\
\hline Illiterates & 21 & 11.54 \\
\hline Primary (upto 7) & 12 & 06.59 \\
\hline High School (8-10) & 114 & 62.64 \\
\hline Intermediate (11-12) & 28 & 15.38 \\
\hline Graduate/Above & 07 & 03.85 \\
\hline Occupation & Number & Percentage (\%) \\
\hline House wife & 84 & 46.15 \\
\hline Private Service & 39 & 21.43 \\
\hline Government service & 21 & 11.54 \\
\hline Labourers/Agriculturists & 38 & 20.88 \\
\hline Socioeconomic status & Number & Percentage (\%) \\
\hline Class I & 09 & 04.94 \\
\hline Class II & 22.64 \\
\hline Class III & 75 & 12.09 \\
\hline Class IV & & 41.21 \\
\hline Class V & 33 & \\
\hline
\end{tabular}

When enquired regarding cancer, $137(75.27 \%)$ women got the information from television. Regarding acquiring the disease $153(84.06 \%)$ and $43(23.62 \%)$ told that it is because of environment and genetic factors respectively. Once the disease is acquired, $89(48.90 \%)$ told that they will have lump and more than $53 \%$ women were aware that it can be diagnosed by blood and radiological examination (Table 2). 
Table 2: Awareness regarding information on cancer* $(\mathrm{n}=182)$.

\begin{tabular}{|c|c|c|}
\hline $\begin{array}{l}\text { Source of } \\
\text { information }\end{array}$ & Number & Percentage (\%) \\
\hline Television & 137 & 75.27 \\
\hline Schools/colleges & 19 & 10.44 \\
\hline Paper & 11 & 06.04 \\
\hline Advertisements & 04 & 02.41 \\
\hline $\begin{array}{l}\text { Others (family } \\
\text { members, friends, } \\
\text { healthcare providers) }\end{array}$ & 37 & 20.33 \\
\hline $\begin{array}{l}\text { Modes of } \\
\text { transmission }\end{array}$ & Number & Percentage (\%) \\
\hline Environment & 153 & 84.06 \\
\hline Genetic & 43 & 23.62 \\
\hline Others & 06 & 13.04 \\
\hline Symptoms & Number & Percentage (\%) \\
\hline Lump & 89 & 48.90 \\
\hline Change in wart $/$ mole & 05 & 02.75 \\
\hline Persistent cough & 25 & 13.74 \\
\hline $\begin{array}{l}\text { Excessive loss of } \\
\text { blood }\end{array}$ & 21 & 11.54 \\
\hline $\begin{array}{l}\text { Change in bowel } \\
\text { habits }\end{array}$ & 14 & 07.69 \\
\hline $\begin{array}{l}\text { Blood from natural } \\
\text { orifices }\end{array}$ & 06 & 03.30 \\
\hline $\begin{array}{l}\text { Unexplained loss of } \\
\text { weight }\end{array}$ & 18 & 09.89 \\
\hline Swelling & 39 & 21.43 \\
\hline Don’t know & 44 & 24.18 \\
\hline $\begin{array}{l}\text { Laboratory } \\
\text { diagnosis }\end{array}$ & Number & Percentage (\%) \\
\hline Blood examination & 112 & 61.54 \\
\hline Urine examination & 10 & 05.49 \\
\hline Stool examination & 04 & 02.20 \\
\hline Radiology & 98 & 53.85 \\
\hline Any others & 08 & 04.40 \\
\hline Don't know & 26 & 14.29 \\
\hline
\end{tabular}

* Multiple answers

$130(71.43 \%)$ opined that disease can be prevented, of which $82(63.08 \%)$ by changing habits and only 19 (14.66\%) told by screening periodically (Table 3 ).

When literacy status was compared with warning symptoms, it was found that $122(88.41 \%)$ literates were more aware than $16(11.59 \%)$ illiterates, which was statistically not significant $\left(\chi^{2}=0.001738\right.$, df $=1, \mathrm{p}=$ 0.9668 not significant, Odds Ratio (OR): $1.023,95 \%$ CI: 0.3519 to 2.974 ) (Table 4).

Table 3: Awareness regarding prevention on cancer.

\begin{tabular}{|lll|}
\hline Prevention & $\begin{array}{l}\text { Number } \\
(\mathbf{n = 1 8 2})\end{array}$ & Percentage (\%) \\
\hline Can be prevented & 130 & 71.43 \\
\hline Cannot be prevented & 52 & 28.57 \\
\hline $\begin{array}{l}\text { Methods of } \\
\text { prevention } *\end{array}$ & $\begin{array}{l}\text { Number } \\
(\mathbf{n = 1 3 0})\end{array}$ & Percentage (\%) \\
\hline $\begin{array}{l}\text { Changing } \\
\text { habits/lifestyles }\end{array}$ & 82 & 63.08 \\
\hline Vaccines & 14 & 10.77 \\
\hline Consult doctor & 34 & 26.15 \\
\hline Screening & 19 & 14.66 \\
\hline
\end{tabular}

* Multiple answers

Table 4: Comparison of literacy status versus warning symptoms* $(\mathbf{n}=182)$.

\begin{tabular}{|lll|l|}
\hline \multirow{2}{*}{$\begin{array}{l}\text { Literacy } \\
\text { Status }\end{array}$} & Yes $(\%)$ & No $(\%)$ & \multirow{2}{*}{ Total $(\%)$} \\
\hline Illiterates & $16(11.59)$ & $05(11.36)$ & $21(11.54)$ \\
\hline Literates & $122(88.41)$ & $39(88.64)$ & $161(88.46)$ \\
\hline Total & $\mathbf{1 3 8}(\mathbf{7 5 . 8 2})$ & $\mathbf{4 4}(\mathbf{2 4 . 1 8})$ & $\mathbf{1 8 2}(\mathbf{1 0 0 . 0 0})$ \\
\hline
\end{tabular}

$*\left(\chi^{2}=0.001738, \mathrm{df}=1, \mathrm{p}=0.9668\right.$ Not Significant, OR: 1.023, $95 \%$ CI: 0.3519 to 2.974$)$

\section{DISCUSSION}

The present study was aimed at assessing the knowledge of women in their reproductive age group towards cancer with an attempt to create awareness about cancer and also about various screening tests available at various hospitals through health education programme.

In the study population, majority of the women were in 20-24 years age group, similar to that of study conducted in Chandigarh ${ }^{13}$ as well as study done in westbengal. ${ }^{4}$

The present study revealed that the almost $62.64 \%$ had completed secondary education which is similar to that of a study conducted among women living in urban slums in Mumbai. ${ }^{3}$

Similar to a previous study carried out in west Bengal ${ }^{4}$ on cancer awareness and also in south Delhi ${ }^{14}$, the participants of this study also belonged to socioeconomic class III and IV. 
Maximum $75.27 \%$ have seen and heard most of the times on television regarding the disease, contrast to other studies done in south Delhi ${ }^{14}$ and Mumbai slums ${ }^{3}$ different sources of information also played a major role in creating awareness of disease.

Among the participants of this study, the awareness about the disease transmission was almost similar to the reports from a study conducted in Chandigarh. ${ }^{13}$

When enquired about the symptoms of cancer only $48.90 \%$ opined that lump will be present and $24.18 \%$ told that they do not know any symptoms of cancer which shows that there is lack of awareness of cancer in our study group when compared with other studies done in west bengal ${ }^{4}$ and Newdelhi ${ }^{15}$ may be because of paucity of awareness campaigns and health education sessions in our slums.

The knowledge about diagnosing the cancer by radiological examination was existent in $53.85 \%$ and only $4.40 \%$ of women were aware that it can be diagnosed by others investigations (pap smears, mammography etc...) which is less compared to other studies in chandigarh ${ }^{13}$ and Mumbai slums. ${ }^{3}$

While $63.08 \%$ women knew that it could be prevented by changing lifestyles, which is more compared to study conducted among women staying in Mumbai slums. ${ }^{3}$ This could be because of better literacy status in our study group.

When literacy status was compared with warning symptoms, it was found that $122(88.41 \%)$ literates were more aware than $16(11.59 \%)$ illiterates, which was statistically not significant $\left(\chi^{2}=0.001738\right.$, df $=1, \mathrm{p}=$ 0.9668, OR: 1.023). This shows that as education level increases the knowledge also improves.

\section{CONCLUSIONS}

Even though majority of the participants were educated upto the high schooling, their knowledge about acquiring cancer was found to be good but it was accompanied with some misconceptions, it is thus imperative to dispel the myths and wrong notions about cancer from minds and replace it with correct knowledge. To achieve this, there is need to educate firstly adolescent girls, women in reproductive age group, family members and teachers in the community. Continuous health education not only improves their knowledge, develops positive attitude and helps in healthy practices. Campaigns to educate the public about cancer symptoms and reduce help-seeking barriers could play a role in promoting early diagnosis. If rightly done, it would serve the purpose of reaching the mass at negligible cost. There is also a need to improve the utilization of screening services for the betterment of the community.

\section{ACKNOWLEDGEMENTS}

We are extremely thankful to all the women who participated in the study, medical social workers for their kind cooperation and timely help, throughout the study period.

\section{Funding: None \\ Conflict of interest: None declared \\ Ethical approval: Not required}

\section{REFERENCES}

1. Gupta S, Rao YN, Agarwal SP, editors. Emerging strategies for cancer control in women of India. In 50 Years of Cancer Control in India, National Cancer Control Programme, Ministry of Health and Family Welfare, Director General of Health Services, Govt. of India, 2002: 184-94.

2. Stubbings $\mathrm{S}$, Robb $\mathrm{K}$, Waller $\mathrm{J}$, Ramirez A, Austoker J, Macleod U, et al. Development of a measurement tool to assess public awareness of cancer. Br J Cancer 2009; 101 Suppl 2: S13-7.

3. Yogesh SK, Mishra G, Gupta S, Shastri S. Level of Cancer Awareness among Women of Low Socioeconomic Status in Mumbai Slums. Asian Pacific J Cancer Prev 2011;12: 1295-298.

4. Ray K, Mandal S. Knowledge about cancer in West Bengal - a pilot survey. Asian Pac J Cancer Prev 2004;5: 205-12.

5. Kishore J. National health programs of India. In: Kishore J, editor. National cancer control program. 6th ed. New Delhi: Century Publications; 2006: 289-90.

6. Ali I, Wani WA, Saleem K. Cancer Scenario in India with future perspectives. Cancer Therapy 2011;8: 56-70.

7. Sabu KM, Pattanshetty S, Darshan BB, Kamath S. Problem of Breast Cancer in South India - A Record based study. Australas Med J 2010;3: 970-73.

8. Dikshit R, Gupta PC, Ramasundarahettige C, Gajalakshmi V, Aleksandrowicz L, Badwe R, et al. Cancer mortality in India : a nationally representative survey. Lancet 2012;379: 1807-16.

9. Adlard JW, Hume MJ. Cancer knowledge of the general public in the United Kingdom: survey in a primary care setting and review of the literature. Clin Oncol 2003;15: 174-80.

10. Chankapa YD, Pal R, Tsering D. Correlates of cervical cancer screening among underserved women. Indian J Cancer 2011;48: 40-6.

11. Dasgupta A, Naskar NN, Ram R, Deb S. A Community Based Study on the Prevalence of Risk Factors of Cancer Cervix in Married Women of a Rural Area of West Bengal. Indian J Community Med 2002;27: 35-8.

12. Gupta MC, Mahajan BK. Text book of preventive and social medicine. In: Gupta MC, Mahajan BK, editors. Social environment. 3rd ed. New Delhi: Jaypee Brothers Medical Publishers; 2003: 117-18. 
13. Puri S, Mangat C, Bhatia V, Kaur AP, Kohli DR. Knowledge of cancer and its risk factors in Chandigarh, India. Int J Epidemiol 2010;8: DOI: 5580/51a.

14. Somdatta P, Baridalyne N. Awareness of breast cancer in women of an urban settlement colony. Indian J Cancer 2008;45: 149-53.
15. Seth T, Kotwal A, Thakur R, Singh P, Kochupillai $\mathrm{V}$. Common cancers in India: knowledge, attitudes and behaviours of urban slum dwellers in New Delhi. Public Health 2005;119: 87-96.

DOI: 10.5455/2320-1770.ijrcog20131204

Cite this article as: Mayur SS, Radhika MS,

Anshuman A. Cancer awareness among females of urban slums in their reproductive age group. Int $\mathbf{J}$

Reprod Contracept Obstet Gynecol 2013;2:509-13. 